\title{
Chiral Phosphinophenyloxazolines Bearing Alkoxymethyl Substituents: Synthesis and Application in the Palladium Catalyzed Allylic Substitution Reactions
}

\author{
Rong-Jiunn Chen ( 陳榮峻) and Jim-Min Fang* ( 方俊民 ) \\ Department of Chemistry, National Taiwan University, Taipei 106, Taiwan, R.O.C.
}

\begin{abstract}
The chiral phosphine-oxazoline ligands 3 and $\mathbf{4}$ bearing 4-alkoxymethyl substituents on the oxazoline ring with $(R)$-configuration were prepared from L-serine methyl ester in $66 \%$ and $33 \%$ yields, respectively. Along this synthetic pathway, the $\beta$-hydroxylamides derived from L-serine methyl ester and 2-halobenzoyl chlorides were expediently converted to the corresponding oxazolines by using diethylaminosulfur trifluoride as the activation agent. Potassium diphenylphosphide was the reagent of choice for replacing the bromine atom on the phenyl ring, giving the desired oxazoline-phosphine ligands 3 and 4 . Together with $\left[\operatorname{Pd}\left(\eta^{3}-\right.\right.$ allyl)Cl1 $]_{2}$, ligands 3 and $\mathbf{4}$ induced an enantioselective allylic substitution reaction of 1,3-diphenyl-2-propenyl acetate by dimethyl malonate. Although ligands $\mathbf{3}$ and $\mathbf{4}$ exhibit the $(R)$-configuration, differing from the $(S)$-configuration of Pfaltz-Helmchen-Williams phosphine-oxazoline ligands, all these ligands led to the same enantiotopic preference in the allylic substitution reaction. To facilitate the recovery and reuse of the phosphine-oxazoline ligand, immobilization on Merrifield resin was attempted, albeit in low loading.
\end{abstract}

Keywords: Phosphine; Oxazoline; Palladium; Chiral ligands; Allylic substitution.

\section{INTRODUCTION}

The chiral ligands prepared by connection of phosphine and oxazoline moieties have been successfully used to promote a variety of metal catalyzed asymmetric organic reactions. ${ }^{1}$ For example, Pfaltz, ${ }^{2}$ Helmchen, ${ }^{3}$ and Williams ${ }^{4}$ groups have independently found the highly enantioselective substitution reaction of 1,3-diphenyl-2-propenyl acetate with dimethyl malonate by the catalysis of a palladium complex 2 that is prepared in situ from the phosphine-oxazoline ligand $\mathbf{1}$ and $\left[\operatorname{Pd}\left(\eta^{3} \text {-allyl }\right) C l\right]_{2} .^{5}$ The $(S)$-configuration of the chiral ligand 1 originates from $(S)$-valinol. We report herein the synthesis of the P,N-ligands $\mathbf{3}$ and $\mathbf{4}$ that bear 4-alkoxymethyl substituents on the oxazoline ring. In addition to the phosphorus and nitrogen atoms, the 4-alkoxymethyl group may also serve as a coordination site for a metal ion to render a stereo- control in organic transformation, such as the Pd-mediated allylic substitution reactions. ${ }^{5}$

\section{RESULTS AND DISCUSSION}

The condensation reaction of L-serine methyl ester (as the hydrochloric salt 5) with 2-chlorobenzoyl chloride (6) in the presence of $\mathrm{Et}_{3} \mathrm{~N}$ gave an amide 7 in $78 \%$ yield (Scheme I). Several attempts to form oxazoline by activation of the hydroxyl group in 7 failed to give the desired cyclization product. For example, treatment of 7 with $p$-TsCl or $\mathrm{SOCl}_{2}$ in the presence of $\mathrm{Et}_{3} \mathrm{~N}$ gave only the elimination product $\mathbf{8}^{6}$ In another approach, the hydroxylamide 7 was heated with $\mathrm{PPh}_{3} / \mathrm{CCl}_{4}$ in the presence of $\mathrm{Et}_{3} \mathrm{~N}$ to afford a mixture of alkene 8 and the desired oxazoline 9 in 27\% and 30\% yields,
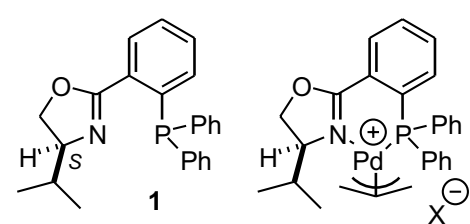

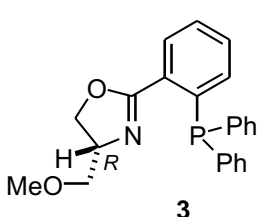

3

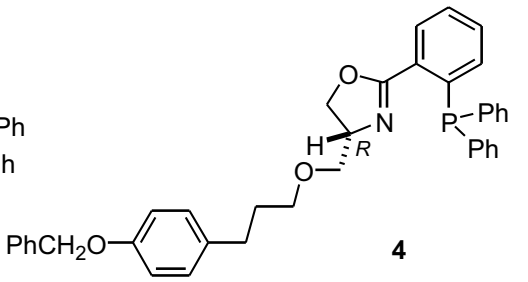

Dedicated to Professor Ching-Erh Lin on the Occasion of his $66^{\text {th }}$ Birthday and his Retirement from National Taiwan University

* Corresponding author. Fax: +886-2-23636359; E-mail: jmfang@ntu.edu.tw 
respectively. Finally, diethylaminosulfur trifluoride (DAST) turned out to be the reagent of choice for the transformation of hydroxylamide 7 into oxazoline $9 .^{7}$ Thus, treatment of 7 with DAST at $-78{ }^{\circ} \mathrm{C}$ in the presence of $\mathrm{K}_{2} \mathrm{CO}_{3}$ gave 9 exclusively in $99 \%$ yield, without complication of the side-product 8. Unlike the valinol derived oxazolines, e.g., compound 1, the oxazoline 9 containing an electron-withdrawing ester group renders the proton at $\mathrm{C}-4$ susceptible to alkaline conditions. Indeed, oxazoline 9 was readily changed to alkene $\mathbf{8}$ upon treatment with a base, e.g., $\mathrm{NaOH}$ and $\mathrm{NaH}$, presumably via the $\mathrm{H}-4$ abstraction to cause a rupture of the oxazoline ring (Scheme I).

\section{Scheme I}<smiles></smiles><smiles>COC(=O)C(=O)NC(=O)c1ccccc1Cl</smiles>

By a procedure similar to that for amide 7 , the acyl chloride derived from 2-bromobenzoic acid (10) was reacted in situ with the serine derivative 5 to give the amide $\mathbf{1 1}$ in $85 \%$ yield (Scheme II). The direct amidation reaction of acid $\mathbf{1 0}$ with 5 was also carried out, albeit in modest yields (50-75\%), by using dicyclohexylcarbodiimide (DCC) or 1-(3-dimethylaminopropyl)-3-ethylcarbodiimide (EDCI) as the dehydrating agents and $\mathrm{Et}_{3} \mathrm{~N}$ and 4-dimethylaminopyridine (DMAP) as the reaction promoters. Hydroxylamide $\mathbf{1 1}$ was then treated with DAST in the presence of $\mathrm{K}_{2} \mathrm{CO}_{3}$ to afford the desired oxazoline $\mathbf{1 2}$ in a quantitative yield. ${ }^{7}$

The reduction of ester 12 with $\mathrm{LiAlH}_{4}$ at room temperature afforded the alcohol 13, which was treated with $\mathrm{NaH}$ and MeI to give the ether $\mathbf{1 4}$ in a $92 \%$ overall yield (Scheme II). One should avoid using excessive amounts of $\mathrm{LiAlH}_{4}$; otherwise, the bromophenyl moiety in $\mathbf{1 2}$ would also be reduced.

\section{Scheme II}<smiles>COC(=O)[C@@H](CO)N[Si]C</smiles>

5

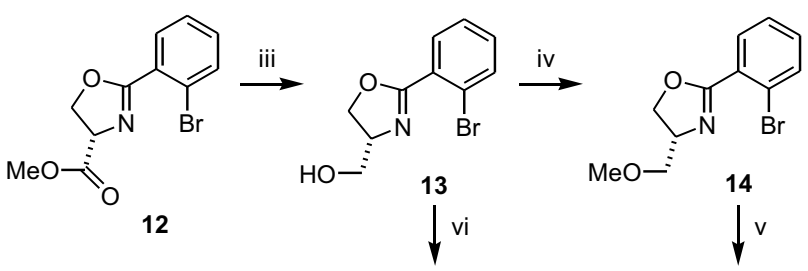

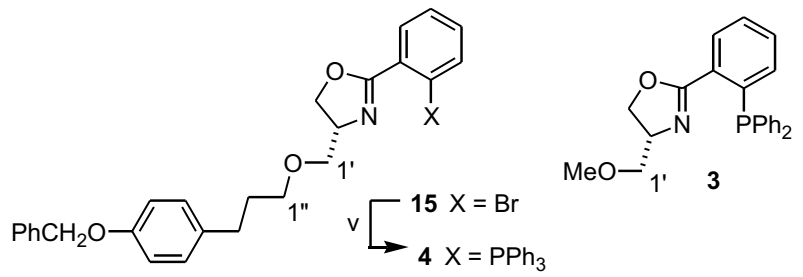

Reagents and conditions: (i) $\mathrm{SOCl}_{2}, 25^{\circ} \mathrm{C}, 3 \mathrm{~h} ; \mathrm{Et}_{3} \mathrm{~N}, \mathrm{CH}_{2} \mathrm{Cl}_{2}$, $25{ }^{\circ} \mathrm{C}, 4 \mathrm{~h} ; 85 \%$. (ii) DAST, $\mathrm{CH}_{2} \mathrm{Cl}_{2},-78{ }^{\circ} \mathrm{C}, 1 \mathrm{~h} ; \mathrm{K}_{2} \mathrm{CO}_{3},-78$ ${ }^{\circ} \mathrm{C}, 3$ h; $99 \%$. (iii) $\mathrm{LiAlH}_{4} / \mathrm{Et}_{2} \mathrm{O}$, THF, $25{ }^{\circ} \mathrm{C}, 4 \mathrm{~h}$; $95 \%$. (iv) $\mathrm{NaH}, \mathrm{MeI}, \mathrm{THF}, 25^{\circ} \mathrm{C}, 3 \mathrm{~h}$; $96 \%$. (v) $\mathrm{KPPh}_{2}$, THF, $25^{\circ} \mathrm{C}, 24 \mathrm{~h}$; $86 \%$ for 3 and $75 \%$ for 4 . (vi) $\mathrm{NaH}, \mathrm{PhCH}_{2} \mathrm{OC}_{6} \mathrm{H}_{4}\left(\mathrm{CH}_{2}\right)_{3} \mathrm{Br}$, $\mathrm{Ag}_{2} \mathrm{CO}_{3}$, THF/DMF $(5: 1), 0{ }^{\circ} \mathrm{C}, 5 \mathrm{~h} ; 58 \%$.

The alkylation reaction of alcohol $\mathbf{1 3}$ with 1-benzyloxy-4(3-bromopropyl)benzene was achieved in THF/DMF $(5: 1)$ solution by the assistance of $\mathrm{Ag}_{2} \mathrm{CO}_{3}$, giving ether 15 in 58\% yield. Substitution of bromine atom with diphenylphosphine group was not trivial as one would expect. We have tried several methods using different combinations of reagents, e.g., $\mathrm{BuLi}$ (or $t$-BuLi) $/ \mathrm{Ph}_{2} \mathrm{PCl}$ in tetramethylethylenediamine (TMEDA), $\mathrm{Li}$ (or $\mathrm{Mg}$ ) $/ \mathrm{Ph}_{2} \mathrm{PCl}\left(\right.$ or $\mathrm{PPh}_{3}$ ) in various conditions, and even with catalysts of $\mathrm{CuI}$ or $\mathrm{Pd}\left(\mathrm{PPh}_{3}\right)_{2} \mathrm{Cl}_{2}$, but failed to procure the desired substitution product. ${ }^{8}$ Finally, the bromophenyl compounds $\mathbf{1 4}$ and $\mathbf{1 5}$ were reacted with $\mathrm{KPPh}_{2}$ to afford the desired oxazoline-phosphine ligands 3 and $4 .{ }^{9}$ The ${ }^{1} \mathrm{H}$ NMR spectra indicated that the aromatic protons $\left(\mathrm{H}_{3}\right.$ ") at the ortho-position of the $\mathrm{PPh}_{2}$ group appeared at the relatively high fields of $\delta 6.49$ (for 3 ) and 6.86 (for 4), presumably due to the shielding effect of the phenyl group in a pseudo-equatorial orientation (Fig. 1, see below). The methylene protons $\left(\mathrm{H}_{1}\right)$ adjacent to the methoxy group in $\mathbf{3}$ also appeared at the relatively high fields of $\delta 2.44$ and 2.66, presumably due to the shielding effect of the pseudo-axial phenyl group. The optimal yields of $3(86 \%)$ and $\mathbf{4}(75 \%)$ were procured by stirring 14 and $\mathbf{1 5}$, respectively, with 5 equiv of $\mathrm{KPPh}_{2}$ in $\mathrm{THF}$ at room temperature for $24 \mathrm{~h}$. Use of less 
amounts (1-3 equiv) of $\mathrm{KPPh}_{2}$ resulted in lower yields. When 15 was heated with $\mathrm{KPPh}_{2}$ in refluxing THF $\left(68^{\circ} \mathrm{C}\right)$, a complicated product mixture containing the alcohol 13 and 3-(4benzyloxyphenyl)propanol, in addition to the desired phosphine product 4 , was obtained in considerable amounts. The cleavage of ether linkage in $\mathbf{1 5}$ might result from the nucleophilic attack at the carbinyl carbons (C-1' and $\left.\mathrm{C}-\mathrm{1}^{\prime \prime}\right)$ by diphenylphosphine or bromine anions.

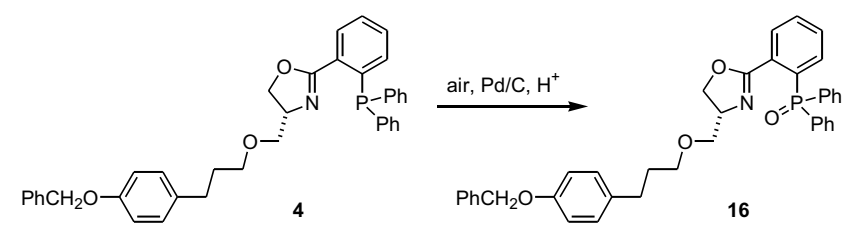

Phosphine 4 were partially oxidized in the air by the catalysis of $\mathrm{Pd} / \mathrm{C}$ under acidic conditions, ${ }^{10}$ e.g., in $\mathrm{AcOH} / \mathrm{MeOH}$ solution $(1: 10)$, to give the corresponding phosphine oxide 16. The characteristic trivalent phosphorus signal in 4 occurred at $\delta-22.96$ in the ${ }^{31} \mathrm{P}$ NMR spectrum, whereas the pentavalent phosphorus in $\mathbf{1 6}$ appeared at a much lower field of $\delta 32.76$.

Interestingly, treatment of the chlorophenyl oxazoline 9 with $t$ - $\mathrm{BuLi} / \mathrm{Ph}_{2} \mathrm{PCl}$ in $\mathrm{Et}_{2} \mathrm{O}\left(-78\right.$ to $25^{\circ} \mathrm{C}, 18 \mathrm{~h}$ ) gave a $32 \%$ yield of $\mathbf{1 7}$ with retention of the chlorine atom. By the chelation effect of the neighboring oxazoline moiety, ${ }^{11}$ compound 9 might undergo the ortho-lithiation, and then react with $\mathrm{Ph}_{2} \mathrm{PCl}$ to afford the product 17.

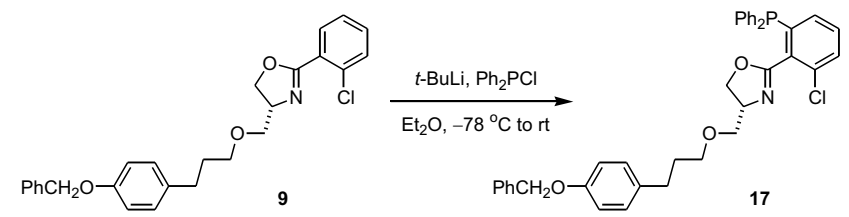

With compounds $\mathbf{3}$ and $\mathbf{4}$ in hand, a wide range of asymmetric organic reactions with catalysis of transition metals could be assessed by using these chiral oxazoline-phosphine ligands. ${ }^{1-5}$ To demonstrate this possible application of compounds 3 and 4 , we firstly investigated the substitution reaction of 1,3-diphenyl-2-propenyl acetate (18) with dimethyl malonate by the catalysis of $\left[\mathrm{Pd}\left(\eta^{3} \text {-allyl }\right) \mathrm{Cl}\right]_{2} \cdot{ }^{5}$ According to the previously reported reaction protocol, ${ }^{12} \mathrm{~N}, \mathrm{O}$-bis(trimethylsilyl)acetamide (BSA) and a base (KOAc or CsOAc) were also used as the promoters in addition to the chiral ligands ( 3 or 4). The best result (entry 4, Table 1), in 96\% chemical yield and $90 \%$ ee, was obtained from the reaction using 3 equiv of dimethyl malonate, $20 \mathrm{~mol} \%$ of ligand 3, $5 \mathrm{~mol} \%$ of
$\left[\mathrm{Pd}\left(\eta^{3} \text {-allyl }\right) \mathrm{Cl}\right]_{2}, 1 \mathrm{~mol} \%$ of $\mathrm{CsOAc}$ and 10 equiv of BSA in $\mathrm{CH}_{2} \mathrm{Cl}_{2}$ solution. By comparison with the previous reports, ${ }^{13}$ the optically active product 19 with levorotation predominated in the $(S)$-enantiomer. The ee value was determined by HPLC analysis on a Chiralcel OD column, where the $(S)$-enantiomer was more polar than the $(R)$-enantiomer. Using ligand $\mathbf{4}$ for the allylic substitution reaction resulted in the same stereoselectivity, albeit in modest enantioselectivity ( $\leq$ $65 \%$ ee).

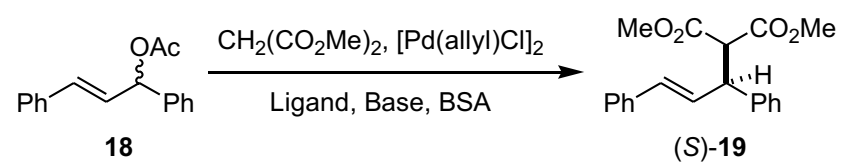

In comparison, the $(R)$-configuration in ligands $\mathbf{3}$ and $\mathbf{4}$ (the alkoxymethyl substituents shown on the $\alpha$-face) differs from the $(S)$-configuration in ligand $\mathbf{1}$ (the isopropyl substitutent shown on the $\beta$-face). However, either the $(S)$-ligand 1 or the $(R)$-ligands $\mathbf{3} / \mathbf{4}$ induced the same enantiotopic preference in the allylic substitution reaction, giving $(S)-\mathbf{1 9}$ as the dominant product. The rationale for the stereoselectivity using ligand $\mathbf{1}$ has been proposed by Helmchen and coworkers. ${ }^{3,5}$ Their proposed transition state (Fig. 1a) includes several important features: (i) the isopropyl substituents on the oxazoline ring forces the triarylphosphine scaffold to tilt toward the $\pi$-allyl moiety, (ii) the $\pi$-allyl moiety prefers the exoorientation to minimize the steric effect against the pseudoequatorial phenyl group on the phosphorus center, and (iii) the nucleophilic attack of dimethyl malonate occurs at C-1 that is trans to the phosphorus atom. On the other hand, the alkoxy group in ligand $\mathbf{3}$ (or $\mathbf{4}$ ) can coordinate to the palladium, and thus exposes the less hindered exo-face to accommodate the $\pi$-allyl moiety (Fig. 1b). These two working models interpret well how the allylic substitution reaction occurs in a highly stereoselective manner to afford the product pre-
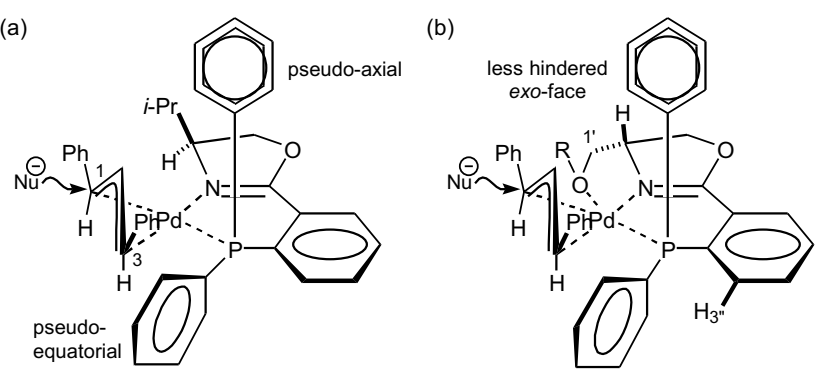

Fig. 1. Working models for the enantioselective allylic substitution reactions: (a) using $(S)$-ligand $\mathbf{1}$, and (b) using ( $R$ )-ligand $\mathbf{3}$ or $\mathbf{4}$. 
Table 1. Allyllic substitution reactions of 1,3-diphenyl-2-propenyl acetate (18) with dimethyl malonate using $\left[\operatorname{Pd}\left(\eta^{3}-\right.\right.$ allyl)Cl $]_{2}$ and chiral ligand ( 3 or 4$)$, giving product $19^{\mathrm{a}}$

\begin{tabular}{|c|c|c|c|c|c|c|c|c|c|}
\hline Entry & $\begin{array}{l}\text { Ligand } \\
(\mathrm{mol} \%)\end{array}$ & $\begin{array}{c}{[\mathrm{Pd}(\text { allyl }) \mathrm{Cl}]_{2}} \\
(\mathrm{~mol} \mathrm{\%})\end{array}$ & $\begin{array}{c}\text { Base } \\
(\mathrm{mol} \mathrm{\%})\end{array}$ & $\begin{array}{l}\text { BSA } \\
\text { (equiv) }\end{array}$ & Solvent & $\begin{array}{l}\text { Reaction } \\
\text { time }(\mathrm{h})\end{array}$ & $\begin{array}{l}\text { Yield } \\
(\%)\end{array}$ & $\begin{array}{l}\mathrm{Ee} \\
(\%)\end{array}$ & Config. ${ }^{\mathrm{b}}$ \\
\hline 1 & $3(10)$ & 5 & KOAc (150) & 0 & $\mathrm{CH}_{2} \mathrm{Cl}_{2}$ & 72 & 0 & - & - \\
\hline 2 & $3(10)$ & 5 & KOAc (5) & 3 & $\mathrm{CH}_{2} \mathrm{Cl}_{2}$ & 48 & 21 & 3 & $\mathrm{ND}^{\mathrm{c}}$ \\
\hline 3 & $3(10)$ & 5 & KOAc (5) & 3 & $\mathrm{CH}_{2} \mathrm{Cl}_{2} / \mathrm{DMF}$ & 48 & 70 & 49 & $S$ \\
\hline 4 & $3(20)$ & 5 & $\mathrm{CsOAc}(1)$ & 10 & $\mathrm{CH}_{2} \mathrm{Cl}_{2}$ & 48 & 96 & 90 & $S$ \\
\hline 5 & $3(20)$ & 5 & CsOAc (1) & 10 & $\mathrm{CH}_{3} \mathrm{CN}$ & 48 & 98 & 79 & $S$ \\
\hline 6 & $4(20)$ & 10 & KOAc (5) & 1.5 & $\mathrm{CH}_{2} \mathrm{Cl}_{2}$ & 40 & 96 & 53 & $S$ \\
\hline 7 & $4(20)$ & 10 & KOAc (5) & 1.5 & THF & 54 & 63 & 65 & $S$ \\
\hline 8 & $4(20)$ & 5 & $\mathrm{CsOAc}(1)$ & 10 & $\mathrm{CH}_{2} \mathrm{Cl}_{2}$ & 6 & 97 & 42 & $S$ \\
\hline 9 & $4(20)$ & 5 & $\mathrm{CsOAc}(1)$ & 2 & $\mathrm{CH}_{3} \mathrm{CN}$ & 2 & 98 & 10 & $S$ \\
\hline
\end{tabular}

${ }^{a}$ The reaction was conducted with 3 equiv of dimethyl malonate at $25^{\circ} \mathrm{C}$.

${ }^{\mathrm{b}}$ Configuration of major enantiomer.

${ }^{\mathrm{c}}$ Not determined.

dominating in the $(S)$-isomer. In comparison with the present study, somewhat higher enantioselectivity in the previously reports ${ }^{3,5}$ may be accounted for by the slight orientation twist of the pseudo-equatorial phenyl groups in the two transition states.

Immobilization on polymer and other supports is a general method for facilitation of the recovery and reuse of the ligand and metal catalyst. ${ }^{14}$ In one approach, the benzyl protecting group in $\mathbf{4}$ was removed by treatment with $\mathrm{AlCl}_{3}$ and $N, N$-dimethylaniline, ${ }^{15}$ and the resulting phenol product 20 was reacted with Merrifield resin (chloromethylated polystyrene) in the presence of $\mathrm{Cs}_{2} \mathrm{CO}_{3}$ in DMF to give the resinsupported oxazoline-phosphine ligand 21. ${ }^{16}$ However, the loading of oxazoline-phosphine ligands was rather low, 0.33 $\mathrm{mmol} / \mathrm{g}$ as estimated by elemental analysis of the nitrogen content.

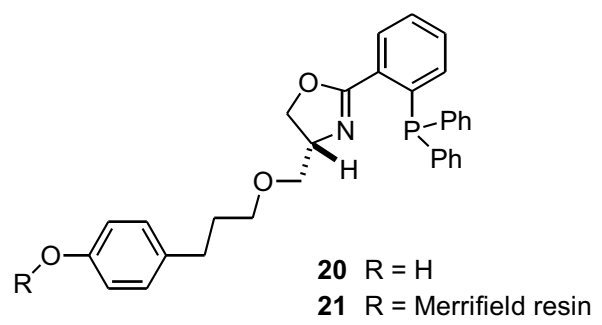

\section{CONCLUSION}

In summary, we have devised an efficient method for the synthesis of chiral oxazoline-phosphine ligands bearing an alkoxymethyl group as the additional coordination site. The use of these chiral ligands has been demonstrated in a palladium catalyzed asymmetric allylic substitution reaction. We are currently searching for an improved preparation of the immobilized oxazoline-phosphine ligands that may be applied to facilitate catalytic asymmetric reactions.

\section{EXPERIMENTAL}

\section{General Procedures}

All reactions requiring anhydrous conditions were conducted in flame-dried apparatus under an atmosphere of argon or nitrogen. Syringes and needles for the transfer of reagents were dried at $100{ }^{\circ} \mathrm{C}$ and allowed to cool in a desiccator over $\mathrm{P}_{2} \mathrm{O}_{5}$ before use. Ethers were distilled from sodium benzophenone ketyl; (chlorinated) hydrocarbons, and amines from $\mathrm{CaH}_{2}$. Reactions were monitored by TLC using precoated with a $0.25 \mathrm{~mm}$ layer of silica gel containing a fluorescent indicator. Column chromatography was carried out on Kieselgel 60 (40-63 $\mu \mathrm{m})$. Melting points are uncorrected. Optical rotations were measured on a digital polarimeter with a cuvette of $10 \mathrm{~cm}$ length. $[\alpha]_{\mathrm{D}}$ Values are given in $10^{-1} \mathrm{deg} \mathrm{cm}^{2}$ $\mathrm{g}^{-1}$. Chemical shifts of ${ }^{1} \mathrm{H},{ }^{13} \mathrm{C}$ and ${ }^{31} \mathrm{P}$ NMR spectra are reported relative to $\mathrm{CHCl}_{3}\left[\delta_{\mathrm{H}} 7.24, \delta_{\mathrm{C}}\right.$ (central line of t) 77.0] and $\mathrm{H}_{3} \mathrm{PO}_{4}\left(\delta_{\mathrm{P}}=0\right)$. Distortionless enhancement polarization transfer (DEPT) spectra were taken to determine the types of carbon signals.

\section{Methyl (S)-2-(2-Chlorobenzamido)-3-hydroxypropanoate} (7)

A mixture of 2-chlorobenzoic acid (11.6 g, $74 \mathrm{mmol})$ and $\mathrm{SOCl}_{2}$ (52 g, $224 \mathrm{mmol}$ ) was stirred at room temperature for $3 \mathrm{~h}$ and then concentrated under reduced pressure to give 
the corresponding 2-chlorobenzoyl chloride. A solution of L-serine methyl ester hydrochloride $(10 \mathrm{~g}, 67 \mathrm{mmol})$ in $\mathrm{CH}_{2} \mathrm{Cl}_{2}(150 \mathrm{~mL})$ and $\mathrm{Et}_{3} \mathrm{~N}(18.9 \mathrm{~g}, 186 \mathrm{mmol})$ were added. The reaction mixture was stirred for $4 \mathrm{~h}$ at room temperature, and quenched by addition of water $(100 \mathrm{~mL})$. The aqueous phase was separated and then extracted with $\mathrm{CH}_{2} \mathrm{Cl}_{2}(100$ $\mathrm{mL})$. The combined organic phase was dried $\left(\mathrm{MgSO}_{4}\right)$, filtered, concentrated, and chromatographed on a silica gel column with elution of EtOAc/hexane (3:7) to give amide 7 $(14.8 \mathrm{~g}, 86 \%)$.

TLC (EtOAc/hexane, $1: 1) R_{f}=0.50 ;[\alpha]_{\mathrm{D}}^{23}=+26.2(c=$ 1.0, $\mathrm{CH}_{2} \mathrm{Cl}_{2}$ ); IR ( $\left.\mathrm{KBr}, \mathrm{cm}^{-1}\right) 3347,2962,1750,1619,1546$, $1377,1217,1060 ;{ }^{1} \mathrm{H} \mathrm{NMR}\left(\mathrm{CDCl}_{3}, 400 \mathrm{MHz}\right) \delta 2.75(\mathrm{t}, J=$ $5.9 \mathrm{~Hz}, \mathrm{OH}), 3.78(\mathrm{~s}, 3 \mathrm{H}), 4.00-4.10(\mathrm{~m}, 2 \mathrm{H}), 4.83(\mathrm{~m}, 1 \mathrm{H})$, $7.15-7.40(\mathrm{~m}, 4 \mathrm{H}), 7.62-7.65(\mathrm{dd}, J=1.2,8.0 \mathrm{~Hz}, 1 \mathrm{H}) ;{ }^{13} \mathrm{C}$ NMR $\left(\mathrm{CDCl}_{3}, 100 \mathrm{MHz}\right) \delta 52.9,55.3,63.3,127.1,130.30$, $130.38,130.9,131.7,134.0,166.5,170.6$; HR-FAB-MS calcd for $\mathrm{C}_{11} \mathrm{H}_{13}{ }^{35} \mathrm{ClNO}_{4}\left(\mathrm{M}^{+}+\mathrm{H}\right): 258.0455$, found: $\mathrm{m} / z$ 258.0526 .

\section{Methyl 2-(2-Chlorobenzamido)-2-propenoate (8) and} (S)-2-(2-Chlorophenyl)-4-methoxycarbonyl-4,5-dihydro1,3-oxazole (9)

A mixture of hydroxylamide $7(200 \mathrm{mg}, 0.77 \mathrm{mmol})$, $\mathrm{PPh}_{3}(300 \mathrm{mg}, 1.2 \mathrm{mmol})$ and $\mathrm{Et}_{3} \mathrm{~N}(120 \mathrm{mg}, 1.2 \mathrm{mmol})$ in $\mathrm{CCl}_{4}(30 \mathrm{~mL})$ was heated under reflux for $24 \mathrm{~h}$. The mixture was concentrated and chromatographed on a silica gel column by elution with EtOAc/hexane (2:8) to give alkene 8 (50 $\mathrm{mg}, 27 \%$ ) and oxazoline 9 (56 mg, 30\%).

Hydroxylamide 7 was treated with DAST, by a procedure similar to that for $\mathbf{1 2}$, to give oxazoline 9 in a quantitative yield.

Alkene 8: TLC (EtOAc/hexane, 3:7) $R_{f}=0.53$; IR ( $\mathrm{KBr}$, $\left.\mathrm{cm}^{-1}\right) 3383,2968,1728,1679,1532,1336,1213,1050 ;{ }^{1} \mathrm{H}$ NMR $\left(\mathrm{CDCl}_{3}, 400 \mathrm{MHz}\right) \delta 3.85$ (s, 3H), 6.00 (br s, 1H), 6.79 (br s, 1H), 7.33-7.44 (m, 3H), 7.69 (dd, $J=7.4,1.8 \mathrm{~Hz}, 1 \mathrm{H})$, 8.50 (br s, NH); ${ }^{13} \mathrm{C} \mathrm{NMR}\left(\mathrm{CDCl}_{3}, 100 \mathrm{MHz}\right) \delta 53.1,109.7$, 127.2, 130.2, 130.5, 130.7, 130.9, 131.8, 134.5, 164.4, 164.8; HR-FAB-MS calcd for $\mathrm{C}_{11} \mathrm{H}_{11} \mathrm{ClNO}_{3}\left(\mathrm{M}^{+}+\mathrm{H}\right): 240.0349$, found: $\mathrm{m} / \mathrm{z} 240.0428$.

Oxazoline 9: TLC (EtOAc/hexane, 3:7) $R_{f}=0.22 ;[\alpha]_{\mathrm{D}}^{23}$ $=+26.9\left(c=0.1, \mathrm{CH}_{2} \mathrm{Cl}_{2}\right)$; IR $\left(\mathrm{KBr}, \mathrm{cm}^{-1}\right) 2958,1733,1694$, $1594,1439,1318,1267,1053 ;{ }^{1} \mathrm{H} \mathrm{NMR}\left(\mathrm{CDCl}_{3}, 400 \mathrm{MHz}\right) \delta$ $3.74(\mathrm{~s}, 3 \mathrm{H}), 4.53(\mathrm{dd}, J=8.8,10.6 \mathrm{~Hz}, 1 \mathrm{H}), 4.63(\mathrm{dd}, J=8.2$, $8.6 \mathrm{~Hz}, 1 \mathrm{H}), 4.92(\mathrm{dd}, J=8.1,10.7 \mathrm{~Hz}, 1 \mathrm{H}), 7.21-7.39$ (m, $3 \mathrm{H}), 7.72(\mathrm{dd}, J=1.7,7.7 \mathrm{~Hz}, 1 \mathrm{H}) ;{ }^{13} \mathrm{C} \mathrm{NMR}\left(\mathrm{CDCl}_{3}, 100\right.$ MHz) $\delta 52.6,68.6,69.5,126.4,126.5,130.6,131.5,131.9$, 133.4, 165.1, 171.2; HR-FAB-MS calcd for $\mathrm{C}_{11} \mathrm{H}_{11} \mathrm{ClNO}_{3}$
$\left(\mathrm{M}^{+}+\mathrm{H}\right): 240.0349$, found: $m / z 240.0427$.

\section{Methyl (S)-2-(2-bromobenzamido)-3-hydroxypropanoate (11)}

Amidation of 2-bromobenzoic acid with L-serine methyl ester hydrochloride, by a procedure similar to that for 7 , gave 11 in $85 \%$ yield. TLC (EtOAc/hexane, 1:1) $R_{f}=0.50$; $[\alpha]_{\mathrm{D}}^{23}=+26.9\left(c=1.0, \mathrm{CH}_{2} \mathrm{Cl}_{2}\right)$; IR $\left(\mathrm{KBr}, \mathrm{cm}^{-1}\right) 3401,3345$, 2961, 1750, 1619, 1542, 1376, 1057; ${ }^{1} \mathrm{H}$ NMR $\left(\mathrm{CDCl}_{3}, 400\right.$ $\mathrm{MHz}) \delta 3.09$ (br s, O브), 3.73 (s, 3H), 3.92-4.07 (m, 2H), 4.76 $(\mathrm{m}, 1 \mathrm{H}), 7.06(\mathrm{~d}, J=5.6 \mathrm{~Hz}, \mathrm{NH}), 7.18-7.30(\mathrm{~m}, 2 \mathrm{H}), 7.47$ $(\mathrm{dd}, J=1.8,7.5 \mathrm{~Hz}, 1 \mathrm{H}), 7.53(\mathrm{dd}, J=1.2,7.9 \mathrm{~Hz}, 1 \mathrm{H}) ;{ }^{13} \mathrm{C}$ $\mathrm{NMR}\left(\mathrm{CDCl}_{3}, 100 \mathrm{MHz}\right) \delta 52.6,55.0,62.7,119.3,127.4$, 129.4, 131.4, 133.3, 136.7, 167.7, 170.5; HR-FAB-MS calcd for $\mathrm{C}_{11} \mathrm{H}_{12}{ }^{79} \mathrm{BrNO}_{4}\left(\mathrm{M}^{+}+\mathrm{H}\right): 301.9950$, found: $\mathrm{m} / z$ 302.0028.

\section{(S)-2-(2-Bromophenyl)-4-methoxycarbonyl-4,5-dihydro- 1,3-oxazole (12)}

A solution of hydroxylamide $11(232 \mathrm{mg}, 0.77 \mathrm{mmol})$ and DAST $(0.12 \mathrm{~mL}, 0.93 \mathrm{mmol})$ in $\mathrm{CH}_{2} \mathrm{Cl}_{2}(30 \mathrm{~mL})$ was stirred at $-78{ }^{\circ} \mathrm{C}$ for $1 \mathrm{~h}$ and then to which was added $\mathrm{K}_{2} \mathrm{CO}_{3}$ $(0.21 \mathrm{~g}, 1.6 \mathrm{mmol})$. The mixture was stirred for $3 \mathrm{~h}$ at $-78^{\circ} \mathrm{C}$, warmed to room temperature, and quenched by slow addition of an aqueous $\mathrm{NaHCO}_{3}$ solution $(5 \%, 50 \mathrm{~mL})$. The mixture was extracted with $\mathrm{CH}_{2} \mathrm{Cl}_{2}(30 \mathrm{~mL} \times 2)$. The combined organic phase was dried $\left(\mathrm{MgSO}_{4}\right)$, filtered, concentrated, and chromatographed on a silica gel column with elution of EtOAc/hexane (3:7) to give oxazoline 12 (216 mg, 99\%). TLC (EtOAc/hexane, $1: 1) R_{f}=0.71 ;[\alpha]_{\mathrm{D}}^{23}=+90.6(c=0.1$, $\left.\mathrm{CH}_{2} \mathrm{Cl}_{2}\right)$; IR $\left(\mathrm{KBr}, \mathrm{cm}^{-1}\right)$ 2957, 1745, 1648, 1592, 1437, 1361, 1211, 1027; ${ }^{1} \mathrm{H}$ NMR $\left(\mathrm{CDCl}_{3}, 400 \mathrm{MHz}\right) \delta 3.80$ (s, 3H), 4.60 $(\mathrm{m}, 1 \mathrm{H}), 4.71(\mathrm{~m}, 1 \mathrm{H}), 4.98(\mathrm{dd}, J=8.0,10.6 \mathrm{~Hz}, 1 \mathrm{H}), 7.24-$ 7.34 (m, 2H), 7.61 (dd, $J=1.0,8.0 \mathrm{~Hz}), 7.72$ (dd, $J=1.8,7.6$ $\mathrm{Hz}, 1 \mathrm{H}) ;{ }^{13} \mathrm{C} \mathrm{NMR}\left(\mathrm{CDCl}_{3}, 100 \mathrm{MHz}\right) \delta 52.8,68.7,69.8$, 121.9, 127.1, 128.9, 131.7, 132.1, 133.9, 165.9, 171.3; HRFAB-MS calcd for $\mathrm{C}_{11} \mathrm{H}_{11} \mathrm{BrNO}_{3}\left(\mathrm{M}^{+}+\mathrm{H}\right): 283.9844$, found: $m / z 283.9922$.

\section{(S)-2-(2-Bromophenyl)-4-hydroxymethyl-4,5-dihydro-1,3- oxazole (13)}

A solution of ester 12 (4.41 g, $15.6 \mathrm{mmol})$ in THF (150 $\mathrm{mL})$ was treated with $\mathrm{LiAlH}_{4}(18.7 \mathrm{~mL}$ of $1 \mathrm{M}$ solution in $\mathrm{Et}_{2} \mathrm{O}$ ) at room temperature for $1 \mathrm{~h}$. After sequential addition of water $(1 \mathrm{~mL})$, aqueous $\mathrm{NaOH}(15 \%, 1 \mathrm{~mL})$ and water $(3$ $\mathrm{mL}$ ), the mixture was filtered through a pad of Celite, and washed with $\mathrm{CH}_{2} \mathrm{Cl}_{2}(50 \mathrm{~mL})$ and $\mathrm{MeOH} / \mathrm{CH}_{2} \mathrm{Cl}_{2}(5: 95,50$ $\mathrm{mL}$ ). The organic phase was concentrated and then chromatographed on a silica gel column with elution of EtOAc to 
give alcohol $13(3.78 \mathrm{~g}, 95 \%)$. TLC $\left(\right.$ EtOAc/hexane, 8:2) $R_{f}=$ $0.26 ;[\alpha]_{\mathrm{D}}^{22}=+58.3\left(c=1.0, \mathrm{CH}_{2} \mathrm{Cl}_{2}\right)$; IR $\left(\mathrm{KBr}, \mathrm{cm}^{-1}\right) 3351$, 2939, 1653, 1591, 1434, 1362, 1250, 1027; ${ }^{1} \mathrm{H} \mathrm{NMR}\left(\mathrm{CDCl}_{3}\right.$, $400 \mathrm{MHz}) \delta 3.55(\mathrm{~m}, 1 \mathrm{H}), 3.57$ (br s, OH), $3.72(\mathrm{~m}, 1 \mathrm{H}), 4.20$ (m, 1H), 4.35 (m, 1H), 7.16-7.24 (m, 2H), 7.52-7.56 (m, 2H); ${ }^{13} \mathrm{C} \mathrm{NMR}\left(\mathrm{CDCl}_{3}, 100 \mathrm{MHz}\right) \delta 63.8,68.3,69.6,121.6,127.0$, 128.2, 129.4, 131.1, 131.7, 133.6, 164.8; HR-FAB-MS calcd for $\mathrm{C}_{10} \mathrm{H}_{11} \mathrm{BrNO}_{2}\left(\mathrm{M}^{+}+\mathrm{H}\right)$ : 255.9895, found: $m / z 255.9974$.

\section{(R)-4-Methoxymethyl-2-(2-bromophenyl)-4,5-dihydro-1,3- oxazole (14)}

A solution of alcohol 13 (3.00 g, $11.8 \mathrm{mmol})$ in THF (30 $\mathrm{mL}$ ) was stirred with $\mathrm{NaH}$ (14.2 mmol, 60\% dispersion in mineral oil washed with anhydrous hexane before use) at room temperature for $10 \mathrm{~min}$. A solution of MeI (1.68 g, 11.8 $\mathrm{mmol})$ in THF $(30 \mathrm{~mL})$ was added dropwise. The mixture was stirred for $3 \mathrm{~h}$, filtered through a pad of Celite, and washed with EtOAc $(50 \mathrm{~mL})$. The organic phase was concentrated and then chromatographed on a silica gel column with elution of EtOAc/hexane (3:7) to give ether 14 (3.04 g, 96\%). TLC (EtOAc/hexane, $1: 1) R_{f}=0.33 ;[\alpha]_{\mathrm{D}}^{22}=+64.4(c=1.0$, $\left.\mathrm{CH}_{2} \mathrm{Cl}_{2}\right)$; IR $\left(\mathrm{KBr}, \mathrm{cm}^{-1}\right)$ 2931, 1651, 1593, 1472, 1358, 1245, 1031; ${ }^{1} \mathrm{H}$ NMR $\left(\mathrm{CDCl}_{3}, 400 \mathrm{MHz}\right) \delta 3.37(\mathrm{~s}, 3 \mathrm{H}), 3.45(\mathrm{~m}$, $1 \mathrm{H}), 3.66(\mathrm{~m}, 1 \mathrm{H}), 4.29(\mathrm{~m}, 1 \mathrm{H}), 4.42-4.53(\mathrm{~m}, 2 \mathrm{H}), 7.22(\mathrm{~m}$, 1H), $7.29(\mathrm{~m}, 1 \mathrm{H}), 7.59$ (dd, $J=7.9,1.3 \mathrm{~Hz}, 1 \mathrm{H}), 7.66$ (dd, $J=$ 7.6, $1.8 \mathrm{~Hz}, 1 \mathrm{H}) ;{ }^{13} \mathrm{C} \mathrm{NMR}\left(\mathrm{CDCl}_{3}, 100 \mathrm{MHz}\right) \delta 58.9,66.3$, 70.3, 74.1, 121.3, 126.6, 129.4, 131.0, 131.3, 133.3, 163.8; HR-FAB-MS calcd for $\mathrm{C}_{11} \mathrm{H}_{13} \mathrm{BrNO}_{2}\left(\mathrm{M}^{+}+\mathrm{H}\right): 270.0051$, found: $m / z 270.0129$.

\section{(R)-4-\{[3-(4-benzyloxyphenyl)propoxy]methyl\}-2-(2- bromophenyl)-4,5-dihydro-1,3-oxazole (15)}

Alcohol 13 treated with $\mathrm{NaH}, \mathrm{Ag}_{2} \mathrm{CO}_{3}$ (1 equiv) and 1-benzyloxy-4-(3-bromopropyl)benzene in THF/DMF (5:1) solution for $5 \mathrm{~h}$ at room temperature, by a procedure similar to that for 14, gave ether $\mathbf{1 5}$ in 58\% yield. TLC (EtOAc/hexane, 3:7) $R_{f}=0.45 ;[\alpha]_{\mathrm{D}}^{24}=+20.0\left(c=1.0, \mathrm{CH}_{2} \mathrm{Cl}_{2}\right)$; IR $(\mathrm{KBr}$, $\left.\mathrm{cm}^{-1}\right) 2928,1652,1512,1456,1356,1240,1025 ;{ }^{1} \mathrm{H}$ NMR $\left(\mathrm{CDCl}_{3}, 400 \mathrm{MHz}\right) \delta 1.87(\mathrm{~m}, 2 \mathrm{H}), 2.63(\mathrm{t}, J=7.3 \mathrm{~Hz}, 2 \mathrm{H})$, 3.47-3.52 (m, 3H), $3.74(\mathrm{dd}, J=7.7,2.5 \mathrm{~Hz}, 1 \mathrm{H}), 4.35-4.40$ $(\mathrm{m}, 1 \mathrm{H}), 4.46-4.55(\mathrm{~m}, 2 \mathrm{H}), 5.02(\mathrm{~s}, 2 \mathrm{H}), 6.89(\mathrm{~d}, J=8.6 \mathrm{~Hz}$, 2H), $7.08(\mathrm{~d}, J=8.6 \mathrm{~Hz}, 2 \mathrm{H}), 7.24-7.45(\mathrm{~m}, 7 \mathrm{H}), 7.62(\mathrm{dd}, J=$ 7.7, $1.0 \mathrm{~Hz}, 1 \mathrm{H}), 7.69(\mathrm{dd}, J=7.7,1.7 \mathrm{~Hz}, 1 \mathrm{H}) ;{ }^{13} \mathrm{C} \mathrm{NMR}$ $\left(\mathrm{CDCl}_{3}, 100 \mathrm{MHz}\right) \delta 31.24,31.28,66.7,69.9,70.5,70.7$, 72.5, 114.6, 121.6, 126.9, 127.3, 127.7, 128.4, 129.2, 129.7, 131.2, 131.5, 133.6, 134.1, 137.1, 156.9, 164.2; HR-FAB-MS calcd for $\mathrm{C}_{26} \mathrm{H}_{27} \mathrm{BrNO}_{3}\left(\mathrm{M}^{+}+\mathrm{H}\right)$ : 480.1096, found: $\mathrm{m} / \mathrm{z}$ 480.1165 .
(R)-4-Methoxymethyl-2-(2-diphenylphosphino)phenyl-4,5dihydro-1,3-oxazole (3)

Under an atmosphere of argon, $\mathrm{KPPh}_{2}$ (1.05 mmol, 2.1 $\mathrm{mL}$ of $0.5 \mathrm{M}$ solution in THF) was added to a solution of the bromophenyl compound 14 (56 mg, $0.21 \mathrm{mmol})$ in THF (3 $\mathrm{mL}$ ). The mixture was stirred at room temperature for $24 \mathrm{~h}$, and then to which was added water $(20 \mathrm{~mL})$ and $\mathrm{CH}_{2} \mathrm{Cl}_{2}(20$ $\mathrm{mL})$. The aqueous phase was separated and then extracted with $\mathrm{CH}_{2} \mathrm{Cl}_{2}(30 \mathrm{~mL})$. The combined organic phase was dried $\left(\mathrm{MgSO}_{4}\right)$, filtered, concentrated, and chromatographed on a silica gel column with elution of EtOAc/pentane (1:9) to give 3 (68 mg, 86\%). TLC (EtOAc/hexane, 3:7) $R_{f}=0.34 ;[\alpha]_{\mathrm{D}}^{22}=$ $+33.3\left(c=1.0, \mathrm{CH}_{2} \mathrm{Cl}_{2}\right)$; IR $\left(\mathrm{KBr}, \mathrm{cm}^{-1}\right) 2928,1643,1536$, 1486, 1299, 1120; ${ }^{1} \mathrm{H} \mathrm{NMR}\left(\mathrm{CDCl}_{3}, 400 \mathrm{MHz}\right) \delta 2.44(\mathrm{dd}, J=$ 13.9, 7.4 Hz, 1H), $2.60(\mathrm{dd}, J=13.9,6.7 \mathrm{~Hz}, 1 \mathrm{H}), 3.27$ (s, $3 \mathrm{H}), 3.50(\mathrm{dd}, J=9.4,4.1 \mathrm{~Hz}, 1 \mathrm{H}), 3.62(\mathrm{dd}, J=9.4,3.3 \mathrm{~Hz}$, $1 \mathrm{H}), 4.42(\mathrm{~m}, 1 \mathrm{H}), 6.49(\mathrm{~d}, J=8.0 \mathrm{~Hz}, 1 \mathrm{H}), 7.24-7.65(\mathrm{~m}$, $13 \mathrm{H}) ;{ }^{13} \mathrm{C} \mathrm{NMR}\left(\mathrm{CDCl}_{3}, 100 \mathrm{MHz}\right) \delta 48.0,58.8,73.6,73.7$, $126.8,128.33,128.38,128.4,128.51,128.58,128.6,128.7$, $131.3,132.61,132.66,132.80,132.85,134.3,137.6,137.7$, 138.3, 138.4, 166.5; ${ }^{31} \mathrm{P}$ NMR $\left(\mathrm{CDCl}_{3}, 162 \mathrm{MHz}\right) \delta-22.87$; HR-FAB-MS calcd for $\mathrm{C}_{23} \mathrm{H}_{23} \mathrm{NO}_{2} \mathrm{P}\left(\mathrm{M}^{+}+\mathrm{H}\right): 376.1388$, found: $m / z 376.1618$.

(R)-4-[3-(4-Benzyloxyphenyl)propoxy]methyl-2-(2-diphenylphosphino)phenyl-4,5-dihydro-1,3-oxazole (4)

Treatment of the bromophenyl compound 15 with $\mathrm{KPPh}_{2}$, by a procedure similar to that for $\mathbf{3}$, gave compound 4 in $75 \%$ yield. TLC (EtOAc/hexane, $3: 7) R_{f}=0.54 ;[\alpha]_{\mathrm{D}}^{23}=$ -12.5 ( $\left.c=1.0, \mathrm{CH}_{2} \mathrm{Cl}_{2}\right)$; IR $\left(\mathrm{KBr}, \mathrm{cm}^{-1}\right) 3064,2926,1641$, $1512,1485,1241,1027 ;{ }^{1} \mathrm{H}$ NMR $\left(\mathrm{CDCl}_{3}, 400 \mathrm{MHz}\right) \delta 1.83$ $(\mathrm{m}, 2 \mathrm{H}), 2.47(\mathrm{dd}, J=7.6,13.8 \mathrm{~Hz}, 1 \mathrm{H}), 2.53-2.69(\mathrm{~m}, 3 \mathrm{H})$, 3.32-3.45 (m, 2H), $3.54(\mathrm{~m}, 1 \mathrm{H}), 3.72(\mathrm{~m}, 1 \mathrm{H}), 4.42(\mathrm{~m}, 1 \mathrm{H})$, $5.01(\mathrm{~s}, 2 \mathrm{H}), 6.86(\mathrm{~d}, J=8.4 \mathrm{~Hz}, 1 \mathrm{H}), 6.88(\mathrm{~d}, J=8.7 \mathrm{~Hz}, 2 \mathrm{H})$, $7.05(\mathrm{~d}, J=8.7 \mathrm{~Hz}, 2 \mathrm{H}), 7.27-7.63(\mathrm{~m}, 18 \mathrm{H}) ;{ }^{13} \mathrm{C} \mathrm{NMR}$ $\left(\mathrm{CDCl}_{3}, 100 \mathrm{MHz}\right) \delta 31.2,31.3,48.2,70.0,70.3,71.6,71.7$, $114.7,126.8,127.4,127.8,128.4,128.49,128.55,128.62$, 128.65, 128.7, 129.2, 131.3, 132.6, 132.7, 132.8, 132.9, 137.1, 138.4, 157.0, 166.6; ${ }^{31} \mathrm{P}$ NMR $\left(\mathrm{CDCl}_{3}, 162 \mathrm{MHz}\right) \delta-22.96$; HR-FAB-MS calcd for $\mathrm{C}_{38} \mathrm{H}_{37} \mathrm{NO}_{3} \mathrm{P}\left(\mathrm{M}^{+}+\mathrm{H}\right): 586.2433$, found: $m / z 586.2503$.

\section{(R)-4-[3-(4-Benzyloxyphenyl)propoxy]methyl-2-(2-diphen-} ylphosphorino)phenyl-4,5-dihydro-1,3-oxazole (16)

Phosphine 4 in $\mathrm{MeOH} / \mathrm{AcOH}$ (10:1) solution was stirred in the air for $18 \mathrm{~h}$ to give phosphine oxide 16. TLC (EtOAc/ hexane, 8:2) $R_{f}=0.34 ;[\alpha]_{\mathrm{D}}^{23}=-13.7\left(c=1.0, \mathrm{CH}_{2} \mathrm{Cl}_{2}\right)$; IR $\left(\mathrm{KBr}, \mathrm{cm}^{-1}\right) 3063,1658,1514,1439,1322,1236,1177,1117$; 
${ }^{1} \mathrm{H}$ NMR $\left(\mathrm{CDCl}_{3}, 400 \mathrm{MHz}\right) \delta 1.79(\mathrm{~m}, 2 \mathrm{H}), 2.53(\mathrm{t}, J=7.6$ $\mathrm{Hz}, 2 \mathrm{H}), 2.68(\mathrm{~m}, 1 \mathrm{H}), 2.95(\mathrm{~m}, 1 \mathrm{H}), 3.12(\mathrm{~m}, 1 \mathrm{H}), 3.26(\mathrm{~m}$, $1 \mathrm{H}), 3.40(\mathrm{t}, J=8.6 \mathrm{~Hz}, 1 \mathrm{H}), 3.68(\mathrm{~m}, 1 \mathrm{H}), 4.52(\mathrm{~m}, 1 \mathrm{H}), 5.01$ (s, 2H), $6.85(\mathrm{~d}, J=8.5 \mathrm{~Hz}, 2 \mathrm{H}), 7.03(\mathrm{~d}, J=8.4 \mathrm{~Hz}, 2 \mathrm{H}), 7.15$ $(\mathrm{m}, 1 \mathrm{H}), 7.24-7.50(\mathrm{~m}, 10 \mathrm{H}), 7.62-7.89(\mathrm{~m}, 7 \mathrm{H}), 8.02(\mathrm{~m}$, $1 \mathrm{H}) ;{ }^{13} \mathrm{C} \mathrm{NMR}\left(\mathrm{CDCl}_{3}, 100 \mathrm{MHz}\right) \delta 31.3,31.4,46.9,70.0$, 70.2, 71.0, 71.1, 114.7, 127.1, 127.4, 127.8, 128.24, 128.36, $128.43,128.53,128.67,128.7,128.8,128.9,129.2,130.3$, 130.4, 130.7, 130.8, 131.1, 131.2, 131.4, 131.9, 133.9, 134.1, 137.1, 156.9, 166.8; ${ }^{31} \mathrm{P} \mathrm{NMR}\left(\mathrm{CDCl}_{3}, 162 \mathrm{MHz}\right) \delta 32.76 \mathrm{ppm}$; HR-FAB-MS calcd for $\mathrm{C}_{38} \mathrm{H}_{37} \mathrm{BrNO}_{4} \mathrm{P}\left(\mathrm{M}^{+}+\mathrm{H}\right)$ : 602.2382, found: $m / z$ 602.2610; Anal. Calcd for $\mathrm{C}_{38} \mathrm{H}_{36} \mathrm{NO}_{4} \mathrm{BrP}$ : C, 75.86; H, 6.03; N, 2.33. Found: C, 75.97; H, 6.12; N, 1.98 .

\section{(R)-4-[3-(4-Benzyloxyphenyl)propoxy]methyl-2-(2-chloro-} 6-diphenylphosphino)phenyl-4,5-dihydro-1,3-oxazole (17)

To a solution of 9 (502 mg, $2.1 \mathrm{mmol})$ in $\mathrm{Et}_{2} \mathrm{O}(20 \mathrm{~mL})$ was added dropwise $t$-BuLi (1.6 mL of $1.5 \mathrm{M}$ solution in THF) at $-78^{\circ} \mathrm{C}$. The mixture was stirred for $3 \mathrm{~h}$; a solution of $\mathrm{ClPPh}_{2}(946 \mathrm{mg}, 4.3 \mathrm{mmol})$ in $\mathrm{Et}_{2} \mathrm{O}(10 \mathrm{~mL})$ was added dropwise at $-78^{\circ} \mathrm{C}$. The reaction mixture was stirred at room temperature for $18 \mathrm{~h}$, quenched by addition of water $(30 \mathrm{~mL})$, and extracted with $\mathrm{CH}_{2} \mathrm{Cl}_{2}(40 \mathrm{~mL} \times 2)$. The organic phase was dried $\left(\mathrm{MgSO}_{4}\right)$, filtered, concentrated, and chromatographed on a silica gel column with elution of EtOAc/hexane (2:8) to give compound 17 (416 mg, 32\%). TLC (EtOAc/hexane, 3:7) $R_{f}=0.54 ;[\alpha]_{\mathrm{D}}^{22}=+40.1\left(c=1.0, \mathrm{CH}_{2} \mathrm{Cl}_{2}\right)$; IR $(\mathrm{KBr}$, $\left.\mathrm{cm}^{-1}\right) 2965,1652,1513,1460,1222,1037 ;{ }^{1} \mathrm{H} \mathrm{NMR}\left(\mathrm{CDCl}_{3}\right.$, $400 \mathrm{MHz}) \delta 1.85(\mathrm{~m}, 2 \mathrm{H}), 2.62(\mathrm{t}, J=7.3 \mathrm{~Hz}, 2 \mathrm{H}), 3.36(\mathrm{t}, J=$ $8.4 \mathrm{~Hz}, 1 \mathrm{H}), 3.45(\mathrm{~m}, 2 \mathrm{H}), 3.65(\mathrm{dd}, J=4.6,9.4 \mathrm{~Hz}, 1 \mathrm{H}), 4.17$ $(\mathrm{m}, 2 \mathrm{H}), 4.38(\mathrm{~m}, 1 \mathrm{H}), 5.03(\mathrm{~s}, 2 \mathrm{H}), 6.89-6.92(\mathrm{~m}, 3 \mathrm{H}), 7.08-$ $7.11(\mathrm{~m}, 2 \mathrm{H}), 7.22-7.24(\mathrm{~m}, 2 \mathrm{H}), 7.31-7.43(\mathrm{~m}, 15 \mathrm{H}) ;{ }^{13} \mathrm{C}$ $\mathrm{NMR}\left(\mathrm{CDCl}_{3}, 100 \mathrm{MHz}\right) \delta 31.2,31.3,66.6,69.9,70.4,70.9$, $72.5,114.6,127.4,127.8,128.42,128.46,128.48,128.49$, $128.5,128.9,129.2,129.3,129.6,130.5,131.7,133.4$, $133.71,133.73,133.81,133.88,133.92,133.94,134.1$, $136.09,136.11,136.21,136.22,137.1,140.5,140.7,156.9$, 162.4; ${ }^{31} \mathrm{P} \mathrm{NMR}\left(\mathrm{CDCl}_{3}, 162 \mathrm{MHz}\right) \delta-8.33$; HR-FAB-MS calcd for $\mathrm{C}_{38} \mathrm{H}_{36} \mathrm{ClNO}_{3} \mathrm{P}\left(\mathrm{M}^{+}+\mathrm{H}\right): 620.2043$, found: $\mathrm{m} / z$ 620.2120 .

\section{Representative Procedure for the Palladium Catalyzed Asymmetric Allylic Substitution Reaction (Table 1)}

A mixture of ligand $4(24 \mathrm{mg}, 0.04 \mathrm{mmol})$ and $[\mathrm{Pd}(\text { allyl }) \mathrm{Cl}]_{2}(7.2 \mathrm{mg}, 0.02 \mathrm{mmol})$ in $\mathrm{CH}_{2} \mathrm{Cl}_{2}(10 \mathrm{~mL})$ was stirred for $10 \mathrm{~min}$. A solution of 1,3-diphenyl-2-propenyl acetate $(50 \mathrm{mg}, 0.2 \mathrm{mmol})$ in $\mathrm{CH}_{2} \mathrm{Cl}_{2}(10 \mathrm{~mL})$ was added, followed by dimethyl malonate $(78 \mathrm{mg}, 0.6 \mathrm{mmol})$, BSA (122 $\mathrm{mg}, 0.6 \mathrm{mmol})$ and KOAc (1 mg, $0.01 \mathrm{mmol})$. The mixture was stirred at room temperature for $40 \mathrm{~h}$, and taken up with $\mathrm{Et}_{2} \mathrm{O}(80 \mathrm{~mL})$. The ethereal solution was washed with saturated $\mathrm{NH}_{4} \mathrm{Cl}(20 \mathrm{~mL} \times 2)$, dried $\left(\mathrm{MgSO}_{4}\right)$, filtered, concentrated, and chromatographed on a silica gel column with elution of EtOAc/hexane (1:9) to give dimethyl 2-(1,3-diphenyl-2-propenyl)malonate (19). A sample of 19 was analyzed by HPLC on a Chiralcel column $(25 \mathrm{~cm} \times 0.46 \mathrm{~cm})$ with elution of 2-propanol/hexane (1:120, flow rate $0.9 \mathrm{~mL})$ using $\mathrm{RI}$ and UV $(254 \mathrm{~nm})$ detectors. $t_{\mathrm{R}}=13.7 \mathrm{~min}(R-19)$ and 14.6 $\min (S-19)$.

(R)-4-[3-(4-Hydroxyphenyl)propoxy]methyl-2-(2-diphenylphosphino)phenyl-4,5-dihydro-1,3-oxazole (20)

To a solution of $4(500 \mathrm{mg}, 0.85 \mathrm{mmol})$ and $\mathrm{AlCl}_{3}(0.34$ g, $2.56 \mathrm{mmol})$ in $\mathrm{CH}_{2} \mathrm{Cl}_{2}(30 \mathrm{~mL})$ was added $N, N$-dimethylaniline ( $1 \mathrm{~g}, 8.5 \mathrm{mmol})$. The mixture was stirred at room temperature for $1 \mathrm{~h}$, filtered through a pad of Celite, and washed with $\mathrm{CH}_{2} \mathrm{Cl}_{2}(20 \mathrm{~mL})$ and EtOAc/hexane $(1: 1,30 \mathrm{~mL})$. The combined organic phase was concentrated and chromatographed on a silica gel column with elution of EtOAc/hexane (1:9) to give phenol 20 (328 mg, 78\%). TLC (EtOAc/hexane, $3: 7) R_{f}=0.33 ;[\alpha]_{\mathrm{D}}^{23}=-23.0,\left(c=1.0, \mathrm{CH}_{2} \mathrm{Cl}_{2}\right)$; IR $\left(\mathrm{KBr}, \mathrm{cm}^{-1}\right)$ $3343,3022,1653,1516,1439,1352,1218 ;{ }^{1} \mathrm{H} \mathrm{NMR}\left(\mathrm{CDCl}_{3}\right.$, $400 \mathrm{MHz}) \delta 1.78-1.85(\mathrm{~m}, 2 \mathrm{H}), 2.48(\mathrm{dd}, J=7.4,14.0 \mathrm{~Hz}$, $1 \mathrm{H}), 2.55(\mathrm{~m}, 2 \mathrm{H}), 2.84(\mathrm{~m}, 1 \mathrm{H}), 3.27-3.42(\mathrm{~m}, 2 \mathrm{H}), 3.54(\mathrm{~m}$, $1 \mathrm{H}), 3.67(\mathrm{dd}, J=3.3,9.5 \mathrm{~Hz}, 1 \mathrm{H}), 4.40-4.47(\mathrm{~m}, 1 \mathrm{H}), 6.37$ (br s, OH), $6.58(\mathrm{~d}, J=8.2 \mathrm{~Hz}, 1 \mathrm{H}), 6.73(\mathrm{~d}, J=8.2 \mathrm{~Hz}, 2 \mathrm{H})$, 6.90-6.98 (m, 2H), 7.23-7.63 (m, 13H); ${ }^{13} \mathrm{C} \mathrm{NMR}\left(\mathrm{CDCl}_{3}, 100\right.$ $\mathrm{MHz}) \delta 30.8,31.2,48.0,70.4,71.6,71.7,115.2,126.9,128.4$, $128.50,128.57,128.62,128.69,128.8,128.9,129.3,131.5$, 132.6, 132.8, 133.2, 134.2, 154.2, 166.9; ${ }^{31} \mathrm{P} \mathrm{NMR}\left(\mathrm{CDCl}_{3}\right.$, $162 \mathrm{MHz}) \delta$-22.45; HR-FAB-MS calcd for $\mathrm{C}_{31} \mathrm{H}_{31} \mathrm{NO}_{3} \mathrm{P}\left(\mathrm{M}^{+}\right.$ $+\mathrm{H})$ : 496.1963, found: $m / z 496.2187$.

\section{A Polymer-Supported Ligand 21}

Merrifield resins (2\% cross-linked, 2-2.5 meq Cl/g, 200-400 mesh) were dried under reduced pressure before use. Under an atmosphere of $\mathrm{N}_{2}$, a mixture of alcohol 20 (500 mg, $1.0 \mathrm{mmol}$ ), Merrifield resins (367 mg, 0.73-0.91 mmol) and $\mathrm{Cs}_{2} \mathrm{CO}_{3}(359 \mathrm{mg}, 1.1 \mathrm{mmol})$ in DMF $(10 \mathrm{~mL})$ was agitated at $60{ }^{\circ} \mathrm{C}$ for $24 \mathrm{~h}$. The mixture was cooled and the resins were collected by filtration and washed successively with 1:1 $\mathrm{H}_{2} \mathrm{O} / \mathrm{THF}(3 \times 25 \mathrm{~mL}), \mathrm{MeOH}(3 \times 25 \mathrm{~mL})$, and THF $(3 \times 25$ $\mathrm{mL}$ ). The product was dried to yield $710 \mathrm{mg}$ of 21. Elemental analysis showed the average nitrogen content of $0.46 \pm$ $0.09 \%$ (three measurements), equivalent to an average loading of $0.33 \mathrm{mmol} / \mathrm{g}$. 


\section{ACKNOWLEDGEMENT}

We thank the National Science Council for financial support.

Received February 21, 2005.

\section{REFERENCES}

1. For reviews, see: (a) Helmchen, G.; Pfaltz, A. Acc. Chem. Res. 2000, 33, 336-345. (b) Pfaltz, A.; Drury, W. J., III. Proc. Natl. Acad. Sci. USA 2004, 101, 5723-5726. For related representative ligands, see: (c) Strangeland, E. L.; Sammakia, T. Tetrahedron 1997, 53, 16503-16510. (d) Gilbertson, S. R.; Chang, C.-W. T. J. Org. Chem. 1998, 63, 8424-8431. (e) Nishibayashi, Y.; Takei, I.; Uemura, S.; Hidai, M. Organometallics 1998, 17, 3420-3422. (f) Zhang, W.; Yoneda, Y.; Kida, T.; Naktshji, Y.; Ikeda, I. Tetrahedron: Asymmetry 1998, 9, 3371-3380. (g) Yonehara, K.; Hashimume, T.; Mori, K.; Ohe, K.; Uemura, S. J. Org. Chem. 1999, 64, 9374-9380. (h) Jiang, Y.; Jiang, Q.; Zhu, G.; Zhang, X. Tetrahedron Lett. 1997, 38, 215-218. (i) Ahn, K. H.; Cho, C.-W.; Park, J.; Lee, S. Tetrahedron: Asymmetry 1997, 8, 1179-1185. (j) Ogasawara, M.; Yoshida, K.; Kamei, H.; Kato, K.; Uozumi, Y.; Hayashi, T. Tetrahedron: Asymmetry 1998, 9, 17791787. (k) Wiese, B.; Helmchen, G. Tetrahedron Lett. 1998, 39, 5727-5730. (1) Hou, D.-R.; Reibenspies, J. H.; Burgess, K. J. Org. Chem. 2001, 66, 206-215. (m) Blankenstein, J.; Pfaltz, A. Angew. Chem., Int. Ed. 2001, 40, 4445-4447. (n) Bernardinelli, G. H.; Kundig, E. P.; Meier, P.; Pfaltz, A.; Radkowski, K.; Zimmermann, N.; Neuburger-Zehnder, M. Helv. Chim. Acta 2001, 84, 3233-3246. (o) Cozzi, P. G.; Zimmermann, N.; Hilgraf, R.; Schaffner, S.; Pfaltz, A. $A d v$. Synth. Cat. 2001, 343, 450-454.

2. von Matt, P.; Pfaltz, A. Angew. Chem., Int. Engl. 1993, 32, 566-568.

3. Sprinz, J.; Helmchen, G. Tetrahedron Lett. 1993, 34, 1769-1772.

4. Dawson, G. J.; Frost, C. G.; Williams, J. M. J. Tetrahedron Lett. 1993, 34, 3149-3150.

5. (a) Helmchen, G. J. Organomet. Chem. 1999, 576, 203-214. Steinhagen, H.; Reggelin, M.; Helmchen, G. Angew. Chem., Int. Ed. Engl. 1997, 36, 2108-2110. (b) Kollmar, M.; Goldfuss, B.; Reggelin, M.; Rominger, F.; Helmchen, G. Chem. Eur. J. 2001, 7, 4913-4927. (c) Kollmar, M.; Steinhagen, H.; Janssen, J. P.; Goldfuss, B.; Malinovskaya, S. A.; Vazquez, J.; Rominger, F.; Helmchen, G. Chem. Eur. J. 2002, 8, 3103-3114. (d) Vazquez, J.; Goldfuss, B.; Helmchen, G. J. Organomet. Chem. 2002, 641, 67-70. (e) Apfelbacher, A.; Braunstein, P.; Brissieux, L.; Welter, R. J. Chem. Soc., Dal- ton Trans. 2003, 1669-1674.

6. Peer, M.; de Jong, J. C.; Kiefer, M.; Langer, T.; Rieck, H.; Schell, H.; Sennhenn, P.; Sprinz, J.; Steinhagen, H.; Wiese, B.; Helmchen, G. Tetrahedron 1996, 52, 7547-7583.

7. Phillips, A. J.; Uto, Y.; Wipf, P.; Reno, M. J.; Williams, D. R. Org. Lett. 2000, 2, 1165-1168.

8. (a) Brown, J. M.; Baker, K. V.; Hughs, N.; Skarnulis, A. J.; Sexton, A. J. Org. Chem. 1991, 56, 698-703. (b) Koch, G.; Lloyd-Jones, G. C.; Loiseleur, O.; Pfaltz, A.; Pretot, R.; Schaffner, S.; Schnider, P.; von Matt, P. Recl. Trav. Chim. Pays-Bas 1995, 114, 206-210. (c) Overmann, L. E.; Owen, C. E.; Zipp, G. G. Angew. Chem. Int. Engl. 2002, 41, 38843887.

9. (a) Allen, J. V.; Dawson, G. J.; Frost, C. G.; Williams, J. M. J. Tetrahedron 1994, 50, 799-808. (b) Nagel, U.; Nedden, H. G. Chem. Ber. Recueil 1997, 130, 385-397. (c) Haenel, M. W.; Oevers, S.; Bruckmann, J.; Kuhnigk, J.; Krueger, C. Synlett 1998, 301-303.

10. Read, G.; Urgelles, M. J. Chem. Soc., Dalton Trans. 1986, 1383-1388.

11. (a) Snieckus, V. Chem. Rev. 1990, 90, 879-933. (b) Snieckus, V. NATO ASI Series E: Applied Sciences 1996, 320, 191221. (c) Hartung, C. G.; Snieckus, V. (Ed., Astruc, D.) Modern Arene Chemistry 2002, 330-367.

12. For review of palladium-catalyzed enantioselective allylic substitution reactions: (a) Sesay, S. J.; Williams, J. M. J. $A d v$. Asym. Syn. 1998, 3, 235-271. (b) Acemoglu, L.; Williams, J. M. J. (Ed., Negishi, E.) Handbook of Organopalladium Chemistry for Organic Synthesis 2002, 2, 1945-1979. For related examples: (c) Trost, B. M.; Murphy, D. J. Organometallics 1985, 4, 1143. (d) Loiseleur, O.; Elliott, M. C.; von Matt, P.; Pfaltz, A. Helv. Chim. Acta 2000, 83, 2287-2294. (e) Gibson, C.; Rebek, J., Jr. Org. Lett. 2002, 4, 1887-1890.

13. (a) Evans, D. A.; Campos, K. R.; Tedrow, J. S.; Michael, F. E.; Gagné, M. R. J. Am. Chem. Soc. 2000, 122, 7905-7920. (b) Fukuda, T.; Takehara, A.; Iwao, M. Tetrahedron: Asymmetry 2001, 12, 2793-2799.

14. For the polymer-supported oxazoline ligands: (a) Bolm, C.; Hermanns, N.; Claßen, A.; Muñiz, K. Bioorg. Med. Chem. Lett. 2002, 12, 1795-1798. (b) Burguete, M. I.; Díez-Barra, E.; Fraile, J. M.; García, J. I.; García-Verdugo, E.; GarciaVerdugo, E.; Gonzalez, R.; Herrerias, C. I.; Luis, S. V.; Mayoral, J. A. Bioorg. Med. Chem. Lett. 2002, 12, 1821-1824. (c) Jonsson, C.; Hallman, K.; Andersson, H.; Stemme, G.; Malkoch, M.; Malmstrom, E.; Hult, A.; Moberg, C. Bioorg. Med. Chem. Lett. 2002, 12, 1857-1861.

15. (a) Akiyama, T.; Hirofuji, H.; Ozaki, S. Tetrahedron Lett. 1991, 32, 1321-1324. (b) Akiyama, T.; Hirofuji, H.; Hirose, A.; Ozaki, S. Synth. Commun. 1994, 24, 2179-2185.

16. (a) Dorwald, F. Z. Organic Synthesis on Solid Phase: Supports, Linkers, Reactions; Wiley-VCH: Weinheim, 2002. (b) Talukdar, S.; Chen, R.-J.; Chen, C.-T.; Lo, L.-C.; Fang, J.-M. J. Comb. Chem. 2001, 3, 341-345. 